\title{
PROGRAM PENDAMPINGAN PEREMPUAN BAGI PEGIAT INDUSTRI RUMAHAN
}

\author{
Muhammad Kamaluddin \\ Dosen Universitas Muhammadiyah Cirebon \\ Email:m.kamaluddin@umc.ac.id
}

\begin{abstract}
ABSTRAK
Perempuan ada kalanya suatu saat menjadi penopang ekonomi keluarganya. Utamanya dalam urusan keuangan, ketergantungan mereka kepada laki-laki berpotensi menjadi hal yang kontraproduktif dengan semangat kesetaraaan. Tulisan ini merupakan kajian dari Program Pendampingan Perempuan Pegiat Industri Rumahan KPPPA-RI di Kabupaten Cirebon. Melalui pemetaan berbasis kuisioner, 100 perempuan pengusaha dari dua desa (Grogol dan Mertasinga) di Kecamatan Gunungjati dikategorikan sesuai dengan golongan bidang usaha yang digelutinya. Aspek-aspek penting semisal permodalan, tenaga kerja, bahan baku, alat bantu, kemasan, harga jual, pemasaran dan pembukuan menjadi hal yang fokus diperhatikan.
\end{abstract}

Kata Kunci: Industri Rumahan, Perempuan, Program Pendampingan

\section{ABSTRACT}

There are times when women become the economic support of their families. Primarily in financial matters, their dependence on men has the potential to be counterproductive to the spirit of equality. This paper is a study of the Mentoring Program for Women KPPPA-RI Home Industry Activists in Cirebon Regency. Through questionnaire-based mapping, 100 women entrepreneurs from two villages (Grogol and Mertasinga) in Gunungjati Subdistrict were categorized according to the business sectors they engaged in. Important aspects such as capital, labor, raw materials, tools, packaging, selling prices, marketing and bookkeeping have become the focus of attention.

Keywords: Home Industry, Women, Mentoring Program 


\section{PENDAHULUAN}

Kabupaten Cirebon sebagai daerah yang dipilih di antara 21 daerah Piloting Project Pengembangan Industri Rumahan memasuki tahun ketiga dalam mengawal program dari KPPPA-RI ini. Selama dua tahun terakhir sejak 2016 dan 2017 berbagai kegiatan telah dilaksanakan dalam upayanya memfasilitasi para perempuan pegiat Industri Rumahan agar dapat memajukan usahanya. Maju baik dalam arti kualitasnya dan tentu juga kuantitasnya.

Dalam hal kualitas, 100 perempuan pengusaha Industri Rumahan yang masuk dalam pemetaan program ini dilatih dan diedukasi mengenai berbagai hal yang relevan. Sebagai misal pada tahun 2016 diberikan pelatihan pembukuan keuangan sederhana, pelatihan pengemasan produk usaha, pelatihan pelabelan dan pemasaran, serta pelatihan pengolahan ragam hasil laut sebagai sumber daya alam yang ada di lingkungan mereka berusaha.

Dari masa awal pemetaan, 100 perempuan pegiat Industri Rumahan di Kabupaten Cirebon memang tidak ada satupun yang masuk kategori IR-1. Hal ini dapat diketahui dari kuisioner yang mereka isi yang menyatakan bahwa ratarata lama usaha yang mereka geluti berjalan sudah lebih dari 5 tahunan. Hanya saja polanya berjalan stagnan yang bisa jadi mengakibatkan usahanya seperti berjalan di tempat tanpa ada kemajuan yang signifikan dalam hal pendapatan.

Secara kuantitatif, perihal pendapatan inilah yang kemudian dapat menjadi indikator usaha mereka berkembang atau tidak. Mulai dari besaran modal, harga jual, selisih modal dan penjualan, konon laba yang didapatkan rata-rata hanya cukup untuk sekedar memenuhi kebutuhan hidup sehari-hari. Beberapanya saja yang diketahui memiliki tabungan di Bank sebagai simpanan hasil dari laba usahanya selama ini.

Di samping itu, keberadaan suami dan anak-anak yang tentu saja menjadi perhitungan bahwa pendapatan yang diperoleh juga diperuntukkan untuk mereka. Meskipun bukan sebagai tulang punggung keluarga, para perempuan pegiat Industri Rumahan ini secara insting alami menjadi solusi bagi problem-problem keuangan yang suatu waktu mendera jalannya kehidupan berumahtangga mereka.

Selain itu tipologi masyarakat nelayan yang notabene berkehidupan dengan bergantung pada gejala-gejala alam. Sejatinya kreativitas dituntut 
menjadi kebutuhan bagi setiap masyarakat nelayan yang tahu kapan dan di mana saat-saat dan tempat-tempat yang dapat menghasilkan banyak tangkapan ataupun menghasilkan keuntungan saat melaut.

Jika itu tidak dilakukan, seloroh "nelayan akrab dengan kemiskinan" bisa jadi menjadi mitos yang tidak terpecahkan. Belum lagi jerat renternir yang kerap menawarkan pinjaman uang instan dengan bunga berlipat ganda. Kiranya saat nelayan hendak melaut dan tidak ada modal, renternir seolah menjadi solusinya. Padahal secara sadar mereka akan dibayang-bayangi masalah tagihan hutang yang bisa saja tidak berkesudahan.

Hal-hal itulah yang kemudian juga menjadikan perempuan seolah sebagai jalan keluar dari permasalahan. Pada gilirannya, perempuan usia produktif ada saja yang masuk ke dalam rayuan maut para sponsor penyalur tenaga kerja ke luar negeri. Menjadi buruh migran yang lebih banyak memberi ketidakpastian pun menjadi pilihan. Bekal keterampilan seadanya menjadi nomor dua setelah nomor satu berniat mencari nafkah untuk membantu permasalahan keuangan keluarga.
Dalam hal ini, dua desa (Desa Grogol dan Desa Mertasinga) sasaran Program Pengembangan Industri Rumahan di Kec. Gunungjati, Kab. Cirebon juga diindikasikan memiliki warna masyarakat yang demikian. Beberapa penduduk perempuannya memilih bekerja ke luar negeri menjadi buruh migran di beberapa negara Timur Tengah, Asia Tenggara dan Asia Timur.

Sebagai ukuran juga diketahui melalui kuisioner, hanya beberapa saja pengusaha perempuan pegiat Industri Rumahan yang sampai selesai menamatkan sekolah tingkat atas. Bahkan untuk tingkat perguruan tinggi diketahui hanya satu yang meraihnya. Maka dari itulah program pengembangan Industri Rumahan ini diharapkan dapat memutus lingkaran kemiskinan dan rendahnya tingkat pendidikan para perempuan keluarga pengusaha pegiat Industri Rumahan.

Belum lagi kasus-kasus lain semisal KDRT jikapun masih terjadi, beberapa sebabnya adalah urusan keuangan yang menghimpit kebutuhan. Tidak jarang keluarga nelayan malah melibatkan anak-anaknya yang laki-laki untuk ikut berlayar ke laut mencari tangkapan ikan ataupun rajungan serta sumber daya laut lainnya yang potensial 
untuk dijual. Kesadaran bahwa Industri Rumahan mesti berkembang dan lebih menghasilkan dinisiasi oleh KPPPA-RI bersama Tim Pelaksana Kabupaten untuk mereduksi hal-hal yang cenderung negatif seperti disebutkan di atas. Program yang tentu saja bukan lagi seperti yang sering ada sebelumnya berupa bantuan-bantuan modal uang yang habis dikonsumsi tanpa ada efek produktif dan konstruktif yang signifikan terhadap penerimanya.

\section{METODOLOGI PENELITIAN}

Metode yang digunakan dalam Kegiatan Pendampingan Perempuan Industri Rumahan meliputi kajian pustaka mengenai perempuan dan industri rumahan (Buku Pedoman Pengembangan Industri Rumahan KPPPA-RI), analisis SWOT (Kekuatan, Kelemahan, Peluang, Ancaman) berbasis data rekam jejak tinjauan awal lapangan, pemetaan lapangan dengan kuisioner (Buku Pedoman Pemetaan Industri Rumahan KPPPA-RI), analisis hasil pemetaan kuisioner, dokumentasi audio visual, wawancara mendalam, pelatihan TOT (Pelatihan) bagi Pendamping Lapangan dan Pendampingan serta Pelatihan berkala secara intensif oleh Pendamping Lapangan dan semua OPD yang terkait langsung maupun tidak langsung ihwal perempuan dan pihak-pihak mitra strategis dari lembaga pemerintah, BUMD/N (Badan Usaha Milik Daerah/Negara) maupun $N G O$ (Lembaga Swadaya Masyarakat/Organisasi Masyarakat) yang berkepentingan dalam pengarusutamaan gender.

\section{PEMBAHASAN}

Kegiatan Pengembangan Industri Rumahan di Kabupaten Cirebon dimulai dengan penjajakan serta penandatanganan kerjasama antara KPPPA-RI bersama Pemkab Cirebon pada tahun 2016. Kemudian setelahnya dilakukan pemetaan yang melibatkan Tim Pelaksana Kabupaten bersama enumerator di dua desa tujuan (Desa Grogol dan Desa Mertasinga) dengan menyebar kuisioner untuk mengetahui siapa-siapa saja yang dianggap layak menjadi sasaran program.

Kemudian daripada itu, Tim Pelaksana yang dikoordinatori Bappeda mendapatkan arahan dari KPPPA-RI untuk merancang berbagai program kegiatan yang hendak dilaksanakan selama tiga tahun ke depan mengingat skema pembiayaan program yang tidak seterusnya dicover oleh KPPPA-RI. 


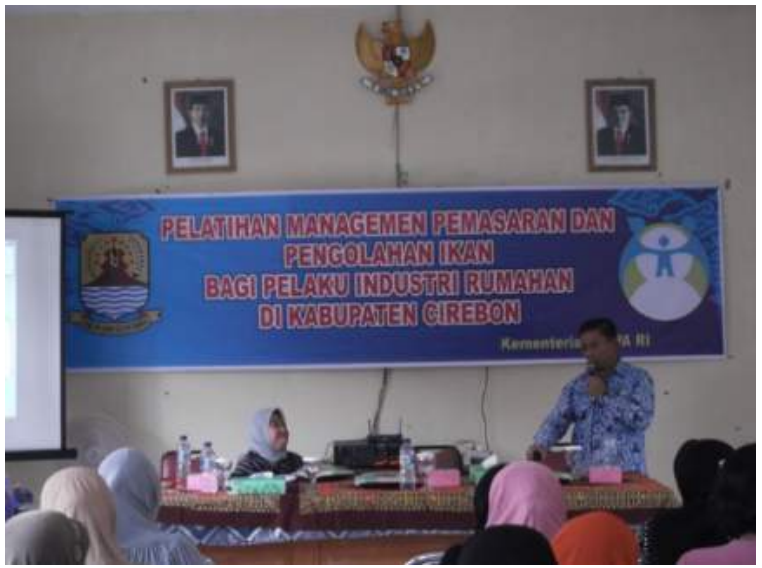

Idealnya, setiap rumusan perencanaan kegiatan, waktu serta pembiayaan dapat direalisasikan sesuai dengan perencanaan. Tetapi yang terjadi tidak sepenuhnya demikian. Mengingat setiap daerah memiliki tata pamong yang relatif tidak sama satu dengan yang lainnya. Kabupaten Cirebon misalnya, saat Kepala Dinas DPPKB masih menjabat, Kepala Bidang PKH yang mengurus urusan perempuan pegiat Industri Rumahan mengalami mutasi beberapa kali selama program berjalan.

Pada gilirannya, kebijakan dan penganggaran yang disusun oleh Kabid awal sebelum mutasi tidak kemudian secara otomatis dapat dipahami bagaimana merealisasikannya oleh Kabid penggantinya kemudian. Memang membingungkan, akan tetapi itu bukan menjadi alasan untuk tetap mengawal program ini berjalan sebagaimana mestinya untuk mencapai tujuan.
Adapun program-program kegiatan pelatihan dan bantuan alat produksi yang telah berhasil direalisasikan selama 20162017 di antaranya, yaitu:

a. Pelatihan Pembukuan Keuangan Sederhana

b. Pelatihan Pengemasan, Pelabelan dan Pemasaran

c. Pelatihan Mengolah Ragam Hasil Laut

d. Bantuan Alat Pendukung Produksi Industri Rumahan

e. Pelatihan Manajemen Pemasaran

f. Pelatihan Pengolahan Ikan Segar

g. Pelatihan PIRT dan Pengajuannya

h. Studi Banding Pembuatan Kripik Pisang di Lampung

i. Pelatihan ICT untuk Pemasaran Produk IR

j. Pelatihan Jejaring Usaha

k. Studi Banding ke Industri Olahan Hasil Laut

1. Pelatihan Membuat Kerajinan Tangan berbahan Limbah

m. Pelatihan Manajemen Peningkatan Produksi Hasil Laut

n. Pelatihan Pengolahan Limbah Produksi Hasil Laut

o. Bantuan Alat Pendukung Produksi Industri Rumahan 


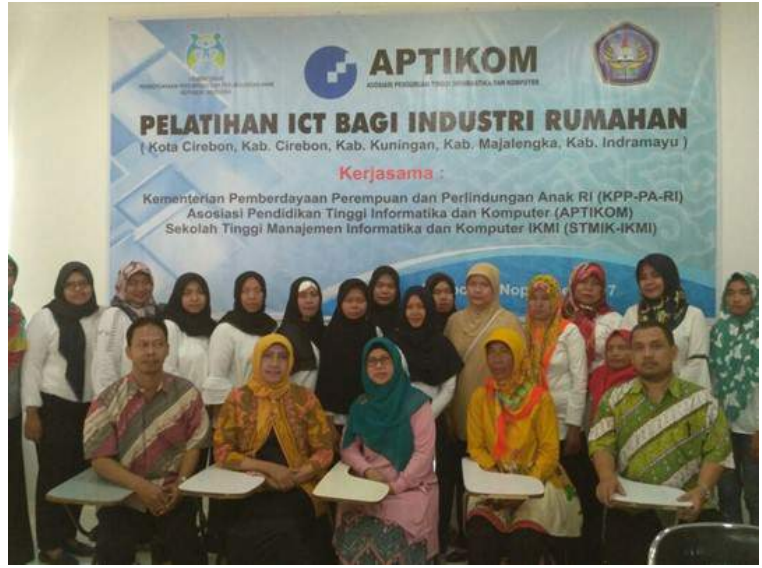

Semua pelatihan di atas telah direalisasikan kepada perempuan pegiat Industri Rumahan di dua desa sasaran (Desa Grogol dan Desa Mertasinga). Beberapa kali juga tercatat perempuan pegiat IR dilibatkan dalam beberapa event bazar yang difasilitasi oleh Pemkab, KPPPA-RI dan atau OPD. Di sinilah ruang sinergi antar OPD dalam perannya bersama-sama ikut mendorong kemajuan para perempuan pegiat Industri Rumahan. Hanya saja beberapa diantaranya bersifat undangan yang terbatas quota. Jadi tidak semua kegiatan di atas dapat diikuti oleh ke 100 orang perempuan pegiat Industri Rumahan dari dua desa sasaran.

Di sisi lain, jalannya program pengembangan Industri Rumahan bagi perempuan pun dilakukan dengan proses pendampingan yang dari awal telah dipilih oleh Tim Pelaksana Kabupaten dan dibekali beberapa kali pelatihan dalam kaitannya dengan keterampilan pendampingan oleh KPPPA-RI. Tim Pendamping yang ditunjuk merupakan unsur dari Perguruan Tinggi dan Organisasi Masyarakat yang concern dalam hal pemberdayaan masyarakat, utamanya perempuan.

Di beberapa kesempatan, Tim Pendamping dapat melaksanakan pendampingan yang sifatnya tatap muka individu door to door secara efektif meskipun memakan waktu yang lebih ekstra. Di saat yang lain ada kalanya Tim Pendamping melakukan pertemuan yang sifatnya menyeluruh bagi setiap desa meskipun tidak terlalu intens.

Hal ini terjadi mengingat saat perempuan IR dikumpulkan bersama membutuhkan tempat yang representatif, aula balai desa. Pada saat bersamaan, ada kalanya pihak Pemdes memaknai ini sebagai kegiatan yang mendapat dukungan dana bagi pesertanya. Tepatnya ada miskomunikasi yang kadang sulit dijelaskan secara verbal karena bisa jadi ini merupakan kekeliruan dalam memahami tata pamong pedesaan mengenai paradigma pelayanan.

Demikian pula dalam beberapa kesempatan, Tim Pendamping menjadi mediator bagi pihak kedua dan ketiga bagi perempuan pegiat IR. Sebagai 
misalnya yaitu Tim Pendamping me-linkkan IR dengan stakeholder penyedia akses permodalan dan jejaring usaha. Pada saat bersamaan juga menjadi juru hubung program-program OPD yang hendak dilaksanakan baik yang berfokus dan atau berlokus di desa perempuan IR.

\section{SIMPULAN}

Realisasi kegiatan Pendampingan Perempuan Pegiat Industri Rumahan di Kabupaten Cirebon dilakukan dalam upaya peningkatan produktivitas usaha mereka agar terus berkembang. Misalnya dalam pembenahan manajemen keuangan, pengendalian mutu produk dan kemasannya, perluasan jejaring pasar penjualan, skema akses permodalan koperasi berbasis komunitas dan hal-hal lain yang telah disebutkan dalam pembahasan.

Di samping itu, hal tersebut juga dilakukan guna mengurangi kesenjangan ekonomi antara perempuan dan laki-laki dalam skala rumahtangga. Baik istri maupun suami misalnya, dalam hal ini dapat lebih saling bersinergi untuk meminimalisir potensi konflik finansial yang bertendensi patriaki. Demikian sehingga slogan untuk mengakhiri kesenjangan (Three Ends) antara perempuan dan laki-laki dalam skala rumahtangga, masyarakat perdesaan bahkan negara dapat semakin nyata tercipta.

\section{DAFTAR PUSTAKA}
KPPPA RI. (2016a). Pedoman Pelaksanaan Kegiatan Pengembangan Industri Rumahan. Jakarta: TIM IR KPPPA RI

\section{KPPPA RI. (2016b). Pedoman Pelaksanaan Pemetaan Industri Rumahan. Jakarta: TIM IR KPPPA RI}

